\title{
Hieronim ze Strydonu jako vir trilinguis na przykładzie komentarza do Iz 7,10-16
}

Hieronim ze Strydonu w pamflecie polemicznym skierowanym przeciw Rufinowi zaświadcza o sobie samym „Ego [...] Hebraeus, Graecus, Latinus, trilinguis" "2. Znajomość języków biblijnych ${ }^{3}$ umożliwiła mu przetłumaczenie Pisma Świętego na język łaciński ${ }^{4}$. Poza przekładem

1 Dr Magdalena Jóźwiak, współpracownik w Pracowni Starożytnego Bliskiego Wschodu i Tradycji Biblijnej w Instytucie Studiów Klasycznych, Śródziemnomorskich i Orientalnych Uniwersytetu Wrocławskiego. Lektor w Szkole Języków Antycznych i Orientalnych przy Wydziale Filologicznym Uniwersytetu Wrocławskiego; e-mail: mjozwiak.uni.wr@gmail.com; ORCID: 0000-0002-1253-1162.

2 Hieronymus, Apologia adversus libros Rufini 3, 6.

3 Hieronimowe zdolności lingwistyczne doceniali inni pisarze chrześcijańscy, jak np. Augustyn z Hippony: „quamvis non defuerit temporibus nostris presbyter Hieronymus, homo doctissimus et omnium trium linguarum peritus, qui non ex Graeco, sed ex Hebraeo in Latinum eloquium easdem scripturas convertit" (Augustinus, De civitate Dei XVIII 43). Wybrane pozycje bibliograficzne traktujące o Hieronimowej znajomości języka hebrajskiego, zob. J. Barr, St. Jerome's Appreciation of Hebrew, BJRL 49 (1967) s. 281-302; E. Burstein, La compétence de Jérôme en hébreu. Explication de certaines erreurs, REAug 21 (1975) s. 3-12; V. Capelli, Segni diacritici ed eredità filologica origeniana in Gerolamo, „Adamantius” 13 (2007) s. 82-101; P.B. Decock, Jerome's turn to the Hebraica veritas and his rejection of the traditional view of the Septuagint, „Neotestamentica. Journal of the New Testament Society of South Africa” 42 (2008) s. 205-222; S. Rebenich, Jerome. The „,Vir Trilinguis” and the „Hebraica Veritas”, VigCh 47 (1993) s. 50-77. Rozszerzony wykaz publikacji na ów temat, zob. M. Jóźwiak, „Princeps exegetarum” a język hebrajski na podstawie „Quaestiones Hebraicae in Genesim”, VoxP 65 (2016) s. 185-186, przyp. 5.

4 Pracę nad Wulgatą Hieronim rozpoczął w czasie pobytu w Rzymie, gdy na zlecenie papieża Damazego dokonał poprawki dostępnego mu przekładu łacińskiego niektórych ksiąg. W oparciu o tekst grecki skorygował przekład Ewangelii oraz Psałterz. W latach 391-406, będąc już w Betlejem, rozpoczął pracę nad przetłumaczeniem Biblii 
Biblii Strydończyk zabłysnął także jako komentator Pisma Świętego, zestawiając niejednokrotnie w swoich komentarzach tekst oryginalny z tłumaczeniami greckimi: LXX, Akwilą, Symmachem i Teodocjonem. Hieronimowe komentarze do ksiąg Starego, jak i Nowego Testamentu w dużej mierze czekają jeszcze na przekłady i opracowanie.

W niniejszym artykule postanowiliśmy pochylić się nad jego komentarzem do Iz 7,10-16 ${ }^{6}$ poszukując odpowiedzi na pytanie, w jaki sposób Strydończyk interpretuje ,proroctwo o Emmanuelu”. Czy ów

na łacinę, posiłkując się hebraica veritas i LXX według heksapli sporządzonej przez Orygenesa. Rzecz jasna kwestią dyskusyjną jest, czy Hieronim rzeczywiście thumaczył wszystkie księgi biblijne czy może poprawiał dostępny mu tekst łaciński Biblii. Uczeni poszukują także odpowiedzi na pytania, jak długo i mozolnie formował się tekst Vulgata editio. Wprowadzenie do tematyki Wulgaty, zob. J. Królikowski, Jak powstała Wulgata i któremu tekstowi Pisma Świętego przystuguje to miano?, TST 36 (2017) s. 5-20.

5 Zob. wykaz pism Strydończyka: M. Jóźwiak, ,Kwestie hebrajskie w Księdze Rodzaju”'św. Hieronima. Przekład i komentarz, Wrocław 2010, s. 18-27.

6 Por. Hieronymus, Commentaria in Isaiam, PL 24, 107 A-113 B. Fragmenty z Hieronimowego dzieła podajemy w tłumaczeniu własnym. Spośród wydań krytycznych Hieronimowego Komentarza do Księgi Izajasza warto wyliczyć Commentaires de Jérôme sur le Prophète Isaïe. Introduction par Roger Gryson. Livres I-IV. Texte établi par Roger Gryson et Paul-Augustin Deproost avec la collaboration de J. Coulie et E. Crousse (=Vetus Latina. Die Reste der altlateinischen Bibel. Aus der Geschichte der lateinischen Bibel, 23), Verlag Herder, Freiburg 1993; Commentaires de Jérôme sur le Prophète Isaïe. Introduction par Roger Gryson et Paul-Augustin Deproost. Livres V-VII. Texte établi par Roger Gryson et J. Coulie avec la collaboration de E. Crousse et V. Somers (=Vetus Latina. Die Reste der altlateinischen Bibel. Aus der Geschichte der lateinischen Bibel, 27), Verlag Herder, Freiburg 1994; Commentaires de Jérôme sur le Prophète Isaïe. Introduction par Roger Gryson. Livres VIII-XI. Texte établi par Roger Gryson et V. Somers avec la collaboration de H. Bourgois et C. Gabriel, (=Vetus Latina. Die Reste der altlateinischen Bibel. Aus der Geschichte der lateinischen Bibel, 30), Verlag Herder, Freiburg 1996; Commentaires de Jérôme sur le Prophète Isaïe. Introduction par Roger Gryson. Livres XII-XVI. Texte établi par Roger Gryson et C. Gabriel avec la collaboration de H. Bourgois et V. Leclercq (=Vetus Latina. Die Reste der altlateinischen Bibel. Aus der Geschichte der lateinischen Bibel, 35), Verlag Herder, Freiburg 1998; Commentaires de Jérôme sur le Prophète Isaïe. Introduction par Roger Gryson. Livres XVI-XVIII. Texte établi par Roger Gryson et C. Gabriel avec la collaboration de H. Bourgois et H. Stanjek (=Vetus Latina. Die Reste der altlateinischen Bibel. Aus der Geschichte der lateinischen Bibel, 36), Verlag Herder, Freiburg 1999. Należy wskazać także na inne, cenne wydanie Hieronimowych wyjaśnień do Księgi Izajasza, które - chociaż nie jest wydaniem krytycznym - stanowi bardzo dobre studium dotyczące dzieła Dalmatyńczyka: Hieronymi, Explanationes in Esaiam. Curavit Robertus Maisano (= Hieronymi opera, 4) \|| Girolamo, Commento a Isaia. A cura di Roberto Maisano (= Opere di Girolamo, 4), I-IV, Città Nuova Editrice, Roma 2013. 
starożytny biblista mesjańską interpretację tego proroctwa wyjaśnia w sensie dosłownym i odnosi ją do Ezechiasza, którego miała porodzić żona króla Achaza, co miało być znakiem trwałości dynastii Dawidowej według obietnicy danej przez Boga (por. 2Sm 7,16.25-26), czy może Hieronim dopatruje się tutaj sensu typicznego i odnosi ów passus do Chrystusa? Spróbujemy także pokazać na wybranych fragmentach, w jaki sposób Hieronim jako vir trilinguis radzi sobie z krytyką tekstu, zestawiając z oryginałem dostępne mu starożytne przekłady Iz 7,10-16.

\section{Słów kilka o Komentarzu do Ksiegi Izajasza autorstwa Hieronima ze Strydonu}

Nad Księgą Izajasza Strydończyk pracował w latach 408-4107. Ów komentarz jest uważany przez badaczy za szczyt Hieronimowej egzegezy ${ }^{8}$.

7 Por. J.N.D. Kelly, Hieronim. Życie, pisma, spory, tł. R. Wiśniewski, Warszawa 2003, s. 343. Hieronim pracę nad komentowaniem Izajasza rozpoczął po ukończeniu komentarza do proroka Daniela, a zakończył ją przed złupieniem Rzymu w 410 roku.

8 Por. M. Simonetti, Między dosłownościa a alegoria, tł. T. Skibiński, Kraków 2000, s. 343. Zob. także: S. Gozzo, De sancti Hieronymi commentario in Isaiae librum, „Antonianum” 35 (1960) s. 169. Wybrana bibliografia do Hieronimowego Komentarza do Księgi Izajasza przedstawia się następująco: J.D. Cassel, Patristic Interpretation of Isaiah, w: ,As Those Who Are Taught”. The Interpretation of Isaiah from the LXX to the $S B L$, ed. C.M. McGinnis - P.K. Tull, Society of Biblical Literature Symposium Series 27, Atlanta 2006, s. 145-170; B. Degórski, Il metodo esegetico di san Girolamo alla luce del «Commento in Isaia», w: Liber Viator. Grandi Commentari del pensiero cristiano, ed. T. Rossi, Studia Pontificiae Universitatis a S. Thoma Aquinate in Urbe. Studi 2004. Nuova serie 8, Roma 2005, s. 173-195; A. Fürst, Hieronymus gegen Origenes. Die Vision Jesajas im ersten Origenismusstreit, REAug 53 (2007) s. 199-231; L. Ginzberg, Die Haggada bei den Kirchenvätern. VI. Der Kommentar des Hieronymus Zu Jesaja, w: Jewish Studies in Memory of George A. Kohut, ed. S.W. Baron - A.M. Baron, New York 1935, s. 279-314; J. Gribomont, La terminologie exégétique de S. Jérôme, w: La Terminologia esegetica nell'antichità. Atti del primo Seminario di antichità cristiane (Bari, 25 ottobre 1984), ed. C. Curti, Quaderni di Vetera Christianorum 20, Bari 1987, s. 123-134; R. GrysonD. Szmatula, Les commentaires patristiques sur Isaïe d'Origène à Jérôme, REAug 36 (1990) s. 3-41; R. Gryson, Saint Jérôme traducteur d'Isaïe. Réflexions sur le texte d'Isaïe 14,18-21 dans la Vulgate et dans l' "In Esaiam», „Le Muséon” 104/1 (1991) s. 57-72; R.G. Jenkins, The Biblical Text of the Commentaries of Eusebius and Jerome on Isaiah, „Ancient Near Eastern Studies” 22 (1984) s. 64-78; B. Löfstedt, Zu Hieronymus'JesaiasKommentar, „Orpheus” 5 (1984) s. 197-203; R. Maisano, L'esegesi di Girolamo ad Isaia, w: Seminario interdisciplinare sul libro del profeta Isaia, ed. R. Maisano - V. Mangogna, 
Jest to jego najobszerniejszy komentarz, ponieważ obejmuje $18 \mathrm{ksiąg}^{9}$. Pracę nad tym dziełem przerywały mu choroby ${ }^{10}$.

Autor Wulgaty Komentarz do Księgi Izajasza dedykował swoim rzymskim przyjaciołom $^{11}$ : Eustochium ${ }^{12}$ (ok. 370-419), Pammachiuszowi ${ }^{13}$ (ok. 340-410) oraz nieżyjącej już Pauli ${ }^{14}$ (ok. 347-404).

W tym komentarzu Hieronim postępował zgodnie ze swoją zwykłą praktyką, podając wyjaśnienie dosłowne i alegoryczne każdego wersetu. Tekst Septuaginty przytaczał jedynie wówczas, gdy odbiegał on bardzo od oryginału hebrajskiego. W rozmaitych dywagacjach filologicznych autor Wulgaty posiłkował się również heksaplą ${ }^{15}$ Orygenesa. Komentarz obfituje

Napoli 2007, s. 101-146; M. Milhau, Commentaires de Jérôme sur le prophète Isaïe, REAug 41 (1995) s. 131-143; M. Simonetti, Sulle fonti del „Commento a Isaia” di Girolamo, „Augustinianum” 24 (1984) s. 451-469.

9 Autor Wulgaty w latach 408-410 najprawdopodobniej skomentował $17 \mathrm{ksiąg}$, księgę piątą zaś podyktował w 397 roku. Tekst ten jest literalnym objaśnieniem dziesięciu przepowiedni z Iz 13-23, które Hieronim napisał na prośbę biskupa Amabilisa. Ta interpretacja została później włączona w kompletny komentarz do Izajasza oraz Strydończyk dodał do niej w księgach szóstej i siódmej interpretację ponaddosłowną tych samych rozdziałów. Por. J. Jay, L'exégèse de Saint Jérôme d'après son „,Commentaire sur Isaïe”, Paris 1985, s. 64; Kelly, Hieronim, s. 253 i 343; Simonetti, Między dosłownością a alegoria, s. 344.

10 Por. Hieronymus, Commentaria in Isaiam XIV Prol.

11 Por. Hieronymus, Commentaria in Isaiam I Prol.

12 W kwestii kobiet, które za sprawą św. Hieronima oddały się życiu ascetycznemu oraz lekturze Pisma Świętego, zob. szerzej: S. Longosz, Hieronim jako duchowy moderator klubu chrześcijańskich arystokratek na Awentynie, w: Przebóstwiać to co ludzkie. Księga pamiątkowa ku czci Księdza Biskupa Władysława Bobowskiego, red. S. Sojka J. Stali, Tarnów 2007, s. 505-525; T. Radliński, Św. Hieronim a kobiety, Lublin 2013; T. Skibiński, Mniszki i egzegetki - kobieta a Pismo Święte w świetle korespondencji świętego Hieronima, w: Kobieta w starożytności chrześcijańskiej. Materiały Sympozjum patrystycznego 22.10.1998 ATK, red. I. Salamonowicz-Górska - T. Skibiński - S. Strękowski, Warszawa $1999=$ SACh 14 (1999) s. 83-91.

13 Na temat tego przyjaciela Hieronima z czasów studiów, rzymskiego senatora, który zostawszy wdowcem, wiódł życie monastyczne, zob. A. Pollastri, Pammachio, DPAC II 2594; P. Szczur, Pammachiusz, EK XIV 1195-1196.

14 Więcej o Pauli i jej córce Eustochium, zob. A. Pollastri, Paola, DPAC II 2607; A. Stępniewska, Żeński klub inteligencji chrześcijańskiej na rzymskim Awentynie IV wie$k u$, VoxP 42-43 (2002) s. 261-292.

15 Jak wiadomo, heksapla dotrwała do naszych czasów tylko we fragmentach. Żyjący w XIX wieku Frederick Field, angielski teolog, zebrał w dwutomowym dziele wszystkie zachowane fragmenty heksapli, które pojawiły się w cytatach Ojców Kościoła i pisarzy chrześcijańskich. Por. F. Field, Origenis Hexaplorum quae super- 
w interesujące uwagi z dziedziny krytyki tekstu i przedstawia jego wersję podawaną w różnych przekładach greckich.

Jeśli chodzi o wyjaśnienia iuxta litteram, to Strydończyk, komentując proroka Izajasza, ma za przedmiot wydarzenia historyczne narodu wybranego. Próbuje, opierając się na swojej wiedzy, objaśniać zwyczaje, jakie panowały w Izraelu za czasów proroka, omawia także tematy botaniczne i zoologiczne, których znajdujemy wiele w Księdze Izajasza. $\mathrm{Z}$ racji tego, iż Strydończyk chciał wykazać, że Izajasz jest „,nie tylko prorokiem, lecz także ewangelistą i apostołem" "16, to w wyjaśnieniach per figuram w wielu passusach czyni nawiązania do Chrystusa i Kościoła ${ }^{17}$.

Praca ta tchnie większą niż zazwyczaj wrogością do Żydów, którym wyrzuca między innymi zaślepienie, niemoralność, chciwość oraz wyraża radość $\mathrm{z}$ ich obecnego poniżenia, a mianowicie $\mathrm{z}$ faktu, że Rzymianie zniszczyli świątynię. Piętnuje również przejawy zła wśród chrześcijan ${ }^{18}$.

Mówiąc o źródłach Hieronimowej egzegezy Izajasza, trzeba zaznaczyć, że jak przeważnie komentator czerpie wyjaśnienia duchowe od aleksandryjczyków. Od Orygenesa ${ }^{19}$ od początku do Iz 30, od Dydyma zaś począwszy od Iz 40. Przy egzegezie dosłownej Hieronim posługuje się przede wszystkim pismami Euzebiusza z Cezarei. Wśród innych greckich autorów, których imiennie wylicza w prologu do omawianego komentarza, pojawia się Apolinary z Laodycei ${ }^{20}$. Jedynym z komentatorów łacińskich, którego Hieronim przywołuje z imienia jest Wiktoryn z Petawium ${ }^{21}$. Szczegółowo o źródłach Hieronimowego komentarza do proroka Izajasza pisał Manlio Simonetti, który nie wyklucza, iż Strydończyk mógł się posługiwać także innymi komentarzami do Izajasza (np. Pseudo-Bazylego,

sunt; sive Veterum Interpretum Graecorum in totum Vetus Testamentum fragmenta, t. I-II, Oxford 1875.

16 Por. Hieronymus, Commentaria in Isaiam I Prol.

17 Por. Simonetti, Między dostownościa a alegoria, s. 344-345.

18 Por. Kelly, Hieronim, s. 345.

19 Ojciec egzegezy alegorycznej objaśniał Księgę Izajasza w systematycznym komentarzu, który niestety nie zachował się do naszych czasów, oraz w licznych homiliach, spośród których dziewięć na język łaciński przetłumaczył Strydończyk. Por. Origenes, In Isaiam hom., ed. W.A. Baehrens, GCS 33, Berlin 1925, s. 242-289, t1. S. Kalinkowski, Orygenes, Homilie o Księdze Izajasza, w: Orygenes, Homilie o Księgach Izajasza i Ezechiela, ŹMT 16, Kraków 2000, s. 15-68.

20 Por. Hieronymus, Commentaria in Isaiam I Prol.

21 Por. Hieronymus, Commentaria in Isaiam I Prol. Zob. M. Dulaey, Victorin de Poetovio, premier exégète latin, Paris 1993; C. Vidal Manzanares, Pisarze wczesnochrześcijańscy I-VIII, w. Mały stownik, tł. E. Burska, Warszawa 2001, s. 89. 
Teodora z Heraklei, Jana Chryzostoma czy też piszącego po łacinie Ambrożego z Mediolanu) oprócz komentatorów, na których autor Wulgaty powołuje się imiennie w prologu do omawianego dzieła ${ }^{22}$.

\section{Hieronimowa egzegeza Iz 7,10-16}

Kontekstem historycznym Izajaszowego proroctwa o Emmanuelu jest tzw. koalicja syro-efraimska, w której dwaj królowie Resin i Pekach wyruszyli zbrojnie przeciwko Judzie (por. Iz 7,1). Na początku tej wojny Achaz utracił Elat, sześć miast Szefeli (por. 2Krn 28,18). Następnie wojska izraelskie z syryjskimi zajęły Judę i przygotowywały oblężenie Jerozolimy. Wieści te przeraziły króla Achaza (por. Iz 7,2) i postanowił wezwać na pomoc Tiglat-Pilesera III, co w konsekwencji ściągnęło polityczną i religijną dominację Asyrii nad Judą. W takich okolicznościach wkracza prorok Izajasz ze słowem YHWH. Izajasz wzywa króla do porzucenia strachu i zaufania Bogu, gdyż Resin i Pekach nie stanowią realnego zagrożenia dla Jerozolimy (Iz 7,4: „Uważaj, bądź spokojny, nie bój się! Niech twoje serce nie słabnie $\mathrm{z}$ powodu tych dwóch oto niedopałków dymiących głowni"), nad którą czuwa Bóg na mocy przymierza zawartego z Dawidem (por. 2Sm 7,16). Syria i Izrael upadną wedle słów proroka (por. Iz 7,8b), a Achaz powinien złożyć całą ufność w YHWH, co stanowi warunek ocalenia Judy (por. Iz 7,9b). W takim kontekście należy sytuować fragment Iz 7,10-16.

\subsection{Król Achaz - znak}

Podczas drugiego spotkania Izajasza z Achazem prorok wzywa króla, by prosił Boga o znak (hebr. הis; por. Iz 7,11), który byłby wyrazem opatrzności Bożej, król zaś odpowiada: „Nie będę prosił i nie będę wystawiał na próbę Pana" (Iz 7,12). Hieronim ze Strydonu, komentując ów werset, nazywa Achaza pyszałkiem, bezbożnikiem i czcicielem bóstw, podkreślając, iż postawa króla wynika z jego pychy. Nadto jako vir trilinguis, konfrontując przekłady $\mathrm{z}$ hebrajskim oryginałem ${ }^{23}$, poucza,

22 Zob. M. Simonetti, Sulle fonti del Commento a Isaia di Girolamo, „Augustinianum” 24 (1984) s. 451-469.

${ }^{23}$ Hieronim w swoich komentarzach biblijnych lubił popisywać się znajomością języka hebrajskiego, co z dumą i wyższością podkreślał. Tam, gdzie tylko była sposobność, 
że choć wszyscy tłumacze podali ,nie będę wystawiał na próbę Pana”, to hebr. וְ można także zrozumieć jako ,nie będę wywyższać Pana". A zatem Achaz jako król pyszny nie chce prosić YHWH o znak, bo wówczas uznałby jego wszechmoc:

Nie jest [człowiekiem] pokory, lecz pychy, ponieważ nie chce domagać się znaku od Pana. [...] Chociaż według dwuznaczności przekazu hebrajskiego, w którym czytamy ULO ENASSE ADONAI ${ }^{24}$ i wszyscy podobnie przetłumaczyli, [to znaczy] „nie będę wystawiał na próbę Pana”, można [to także] przeczytać ${ }^{25}$ [jako] „nie będę wywyższać Pana”. Bezbożny król bowiem wiedział, że jeśli poprosi o znak, to otrzyma [go] i Pan zostanie uwielbiony. Otóż, tak czciciel bóstw, który pobudował ołtarze we wszystkich zakątkach ulic i w górach, i w lesistych gajach, nie chce prosić o znak, który byłby wskazówką i zamiast lewitów miał kapłanów pogańskich bóstw ${ }^{26}$.

komentator czynił trafne analogie do „świętego języka”. Oczywiście przy miejscach wątpliwych Strydończyk zazwyczaj szalę przechyla na stronę hebrajskiego. Dla przykładu w Liście 125 wspomina o trudach, które musiał podjąć, by zgłębiać tajniki tego języka: „Gdy byłem młodzieńcem i głucha samotność otaczała mnie zewsząd, nie mogłem znieść napaści grzechu i żaru zmysłów; i chociaż łamałem je częstymi postami, to jednak umysł płonął w myślach. Chcąc go poskromić zwróciłem się z prośbą o naukę do pewnego brata, który był Żydem z pochodzenia; po odbytych studiach, dzięki którym poznałem bystrość Kwintyliana, bujną wymowę Cycerona, powagę Frontona i łagodność Pliniusza, zacząłem się uczyć alfabetu, zastanawiać się nad słowami syczącymi i przydechowymi. Ile w to włożyłem pracy, ile podjąłem trudów, ile razy zwątpiłem, ile razy ustawałem i z gorącego pragnienia, żeby się nauczyć, znów zaczynałem, co wycierpiałem, świadkiem jest moje sumienie i ci, którzy żyli razem ze mną. I dzięki czynię Panu, że z gorzkiego nasienia nauki zbieram słodkie owoce" (Hieronymus, Epistula 125, 12, ŹMT 63, oprac. H. Pietras - M. Ożóg, tł. J. Czuj, Kraków 2011, s. 160).

${ }^{24} \mathrm{~W}$ dużej mierze Hieronimowa wokalizacja słów hebrajskich pojawiająca się w komentarzu do Iz 7,10-16, który stanowi przedmiot tego artykułu, wydaje się co najmniej kuriozalna i niezgodna z zasadami wokalizacji hebrajskiego biblijnego, które dziś są nam znane. Powodów tego stanu rzeczy może być kilka, lecz nie jest to główny cel naszego przedłożenia, dlatego też przeważnie nie odnosimy się krytycznie do rzeczonej kwestii poza przykładami koniecznymi.

25 Należy pamiętać, że pierwotnie hebrajski tekst Biblii był zapisany przy pomocy samych spółgłosek i takim tekstem dysponował autor Wulgaty. Niejednokrotnie rozmaite kombinacje tych samych spółgłosek pozwalają odczytać tekst na wiele możliwych sposobów. Dopiero od VI wieku pojawiają się różne systemy wokalizacji. Ostatecznie w X wieku przyjęto system tyberiadzki jako najbardziej dokładny.

${ }_{26}$ Hieronymus, Commentaria in Isaiam 7, 12: „Non humilitatis est, sed superbiae, quod non vult signum a Domino postulare. [...] Quamquam juxta Hebraei sermonis ambi- 
Następnie Strydończyk doprecyzowuje w komentarzu do Iz 7,13, że ów znak ma związek z obietnicami Boga danymi dla domu Dawidowego. W 2Sm 7,16 Bóg złożył obietnicę, że potomstwo Dawida będzie panować na wieki, a więc król Achaz powinien zachować spokój, bo na mocy tej obietnicy koalicja syro-efraimska ostatecznie poniesie klęskę:

I to należy odnotować, że Achaz, król najbardziej bezbożny nie chciał prosić o znak, [lecz] mowa prorocka odnosi się do domu Dawida, to znaczy do królewskiego pokolenia, o którym wyżej czytamy: I oznajmili to dla domu Dawida, mówiąc: „Sprzysięgły się Syria i Efraim” (Iz 7,2)27.

\subsection{Panna}

Kluczowym wersetem omawianej sekcji jest Iz 7,14: „Oto panna (hebr.

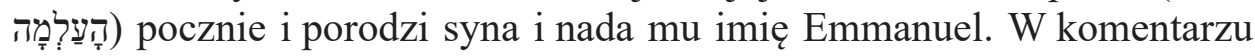
do tego wersetu Książę Egzegetów również zabłysnął jako vir trilinguis. $\mathrm{Na}$ początku bowiem wyjaśnia czytelnikowi znaczenie hebrajskiego

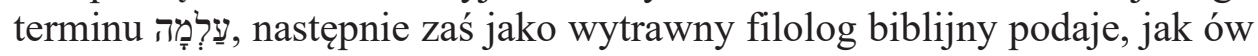
hebrajski termin przełożyli inni starożytni thumacze oraz czyni analogię do Rdz 24,43, gdzie pojawia się także rzeczownik עַלְְמָ w odniesieniu do Rebeki ${ }^{28}$ :

guitatem, in quo scriptum est ULO ENASSE ADONAI, et omnes similiter transtulerunt, «non tentabo Dominum», possit legi, «non exaltabo Dominum». Sciebat enim rex impius quod si signum peteret, accepturus esset, et glorificaretur Dominus. Ergo quasi idolorum cultor, qui in omnibus angulis platearum et in montibus lucisque nemorosis aras constituerat, et pro Levitis habebat fanaticos, non vult signum petere quod praeceptum est" (tł. własne).

27 Hieronymus, Commentaria in Isaiam 7, 13 (tł. własne).

28 Strydończyk w Quaestiones Hebraice in Genesim w sposób następujący komentuje Rdz 24,43: „W Biblii Hebrajskiej napisano: «Stanę obok źródła wody i zjawi się młoda dziewczyna, która przyjdzie, aby zaczerpnąć wody i powiem jej, daj mi napić się troszkę wody z twego dzbana». Zamiast łacińskiego słowa «adolescentu-

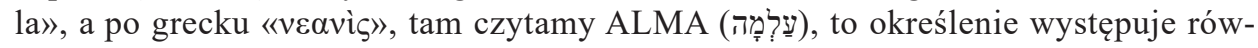
nież u proroka Izajasza. Bowiem, w tym miejscu, gdzie w naszych kodeksach czyta się: «Oto panna pocznie i porodzi» (Iz 7,14), tam Akwila przetłumaczył: «Oto młoda dziewczyna pocznie i porodzi». Natomiast w tekście hebrajskim jest: «Oto dziewczyna na wydaniu pocznie i porodzi». Należy wiedzieć, że słowo «alma» można od-

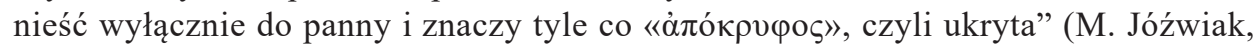


Hebrajskie [słowo] na określenie dziewicy, to BETHULA $^{29}$, którego nie użyto w tym miejscu, lecz zamiast tego słowa czytamy $\mathrm{ALMA}^{30}$, co oprócz tłumaczy Septuaginty ${ }^{31}$ wszyscy przełożyli jako ,adolescentula”. Tymczasem u nich wyraz ALMA jest dwuznaczny, bo może być rozumiany jako ,ado-

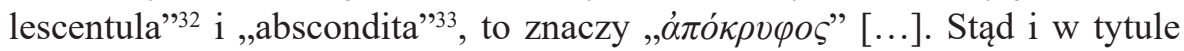
psalmu dziewiątego, gdzie w tekście hebrajskim umieszczono ALAMOTH, wszyscy tłumacze przełożyli [ów wyraz] jako ,pro adolescentia”, tłumacze Septuaginty natomiast zinterpretowali jako ,pro absconditis”. I w Księdze Rodzaju czytamy, że Rebeka została nazwana ALMA (por. Rdz 24), Akwila zaś nie przetłumaczył ani ,,adolescentula”, ani „puella”34, lecz ,abscondita”35.

Następnie, co było zwyczajem Ojców Kościoła i pisarzy chrześcijańskich, jako że „myśleli" niejako Pismem Świętym i interpretowali Biblię w jej świetle, autor Wulgaty, kontynuując rozważania na temat hebrajskiego

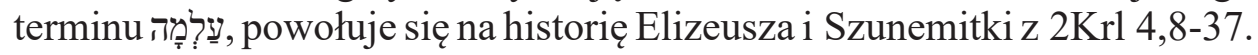

Kwestie hebrajskie w Księdze Rodzaju św. Hieronima. Przekład i komentarz, Wrocław 2010, s. 83).

29 Tutaj Hieronim ma rację. Por. L. Koehler - W. Baumgartner - J.J Stamm, Wielki słownik hebrajsko-polski i aramejsko polski Starego Testamentu, t. 1, red. P. Dec, Warszawa 2008, s. 157-158, nr 1472.

$30 \mathrm{~W}$ opinii badaczy ten rzeczownik można przetłumaczyć jako 'młoda kobieta, dziewczyna na wydaniu, dziewczyna, która jest zdatna do zawarcia małżeństwa'. Ów wyraz podkreśla młodość osoby i normalnie suponuje dziewictwo. Por. Koehler - Baumgartner - Stamm, Wielki stownik hebrajsko-polski, t. 1, s. 779-780, nr 6903. Hieronim ze Strydonu w komentarzu do Iz 7,14, podejmując refleksję nad semantyką omawianego rzeczownika,

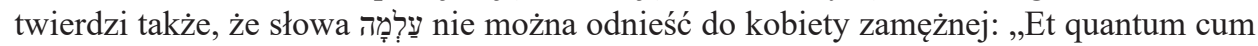
mea pugno memoria, nunquam me arbitror «alma» in muliere nupta legisse, sed in ea quae virgo est: ut non solum virgo sit, sed virgo junioris aetatis, et in annis adolescentiae" (Commentaria in Isaiam 7, 14).

31 Tłumacze LXX przełożyli to słowo przez $\pi \alpha \rho \theta \varepsilon ́ v o \varsigma$ ('dziewica’).

32 To znaczy 'młoda panna, dziewczyna na wydaniu, młoda mężatka'.

33 To znaczy 'ukryta'.

34 To znaczy 'dziewczyna'.

35 Hieronymus, Commentaria in Isaiam 7, 14: ,[...] virgo Hebraice BETHULA appellatur, quae in praesenti loco non scribitur: sed pro hoc verbo positum est ALMA, quod praeter LXX omnes «adolescentulam» transtulerunt. Porro ALMA apud eos verbum am-

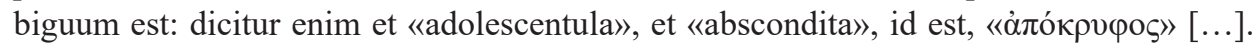
Unde et in titulo psalmi noni, ubi in Hebraeo positum est ALAMOTH, caeteri Interpretes transtulerunt, «pro adolescentia», quod LXX interpretati sunt, «pro absconditis». Et in Genesi legimus: ubi Rebecca dicitur «alma» (Gen XXIV), Aquilam non «adolescentulam», nec «puellam» sed «absconditam» transtulisse" (tł. własne). 
Dalej argumentując swoje racje, w jaki sposób można przetłumaczyć omawiany rzeczownik, odwołuje się do języka punickiego:

Także kobieta z Szunem, straciwszy syna, gdy rzuciła się do nóg Elizeusza, a Gechazi próbował ją powstrzymać, usłyszał od proroka: „Zostaw ją, ponieważ jest w bólu, a Pan ukrył to przede mną" (2Krl 4,27). Tymczasem kiedy w łacińskim [tekście] jest ,abscondit a me”, w hebrajskim czytamy EELIM MEMMENNI. Otóż ALMA, nie tylko znaczy „puella” ${ }^{36}$ lub „virgo" ${ }^{37}$, lecz

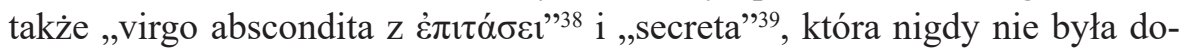
stępna spojrzeniom mężczyzn, lecz jest strzeżona z wielką pilnością rodziców. Także język punicki, o którym twierdzi się, że wypływa ze źródeł [języka] hebrajskiego, słusznie na określenie dziewicy używa [słowa] ALMA ${ }^{40}$.

\subsection{Emmanuel}

Werset z Iz 7,14b w Biblii Tysiąclecia (wyd. 5) przetłumaczono: „I nazwie go imieniem Emmanuel”. Vir trilinguis na początku swoich rozważań do omawianego wersetu sięga po tekst oryginalny, w którym czytamy: „I nazwiesz (hebr. קרָראת) go imieniem Emmanuel”. Następnie wyjaśnia, że tłumacze Septuaginty oraz Akwila, Symmach i Teodocjon formę czasownikową w tym zdaniu także przetłumaczyli przez drugą osobę liczby

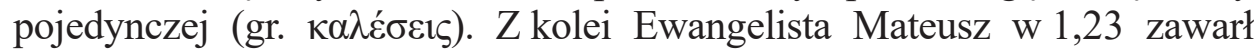

36 To znaczy 'dziewczyna'.

37 To znaczy 'dziewica'.

38 To znaczy 'dziewica ukryta z potomkiem'. Z biologicznego punktu widzenia dziewica posiadająca własne potomstwo jest zjawiskiem, które się wyklucza. Wydaje się, iż Hieronim w tym passusie nawiązuje do potomstwa duchowego lub owa dziewica wedle proroctwa Izajaszowego miałaby być prefigurą Maryi, choć nie pada jej imię. W Quaestiones Hebraice in Genesim 24, 43 Strydończyk także odnosi się do rzeczonej kwestii. Por. Jóźwiak, Kwestie hebrajskie w Księdze Rodzaju św. Hieronima, s. 83-84.

39 Synonim przymiotnika abscondita.

40 Hieronymus, Commentaria in Isaiam 7, 14: „Sunamitis quoque mulier, amisso filio, cum Elisaei fuisset pedibus provoluta, et prohiberet eam Jezi, audit a propheta: «Dimitte eam, quia in dolore est, et Dominus abscondit a me». Pro eo quod in Latino dicitur, «abscondit a me», in Hebraeo scriptum est, EELIM MEMMENNI. Ergo «alma»,

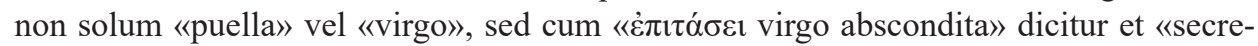
ta», quae nunquam virorum patuerit aspectibus; sed magna parentum diligentia custodita sit. Lingua quoque Punica, quae de Hebraeorum fontibus manare dicitur, proprie virgo «alma» appellatur" (tł. własne). 


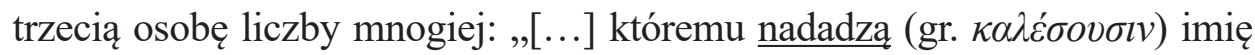
Emmanuel". Dalej autor Wulgaty, lubujący się w wyprowadzaniu etymologii

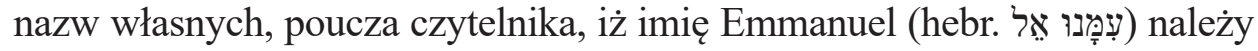
interpretować jako „,z nami Bóg”:

Dalej następuje: „I nazwiesz go imieniem Emmanuel”, i tłumacze Septuaginy i trzej pozostali podobnie przetłumaczyli, stąd u Mateusza napisano, „nazwą”, czego nie ma w [tekście] hebrajskim. Otóż ów chłopiec, który narodzi się z Dziewicy, o domu Dawida, teraz jest nazywany przez ciebie „Emmanuelem” to znaczy „Bogiem z nami”, ponieważ wyzwolony od dwóch nieprzyjaznych królów ${ }^{41}$ udowodnisz tym faktem, że Bóg ma ciebie w swej pieczy ${ }^{42}$.

Komentując Iz 7,14b, Hieronim jako filolog zatrzymuje się nad hebrajskim słowem קָרָאת, które z punktu widzenia gramatyki hebrajskiego biblijnego jest czasownikiem w koniugacji qal perfectum dla drugiej osoby liczby pojedynczej rodzaju żeńskiego od czas. קָרָ ('nadawać imię, wołać') i podaje, że tę formę wszyscy starożytni tłumacze zinterpretowali poprawnie,

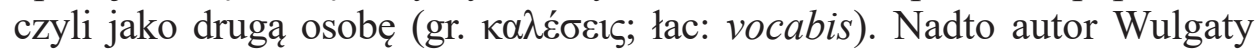
zawiera uwagę, że formę קָרְ także można odczytać jako trzecią osobę liczby pojedynczej. Nie sposób w oparciu o gramatykę wyjaśnić, dlaczego Hieronim zawiera taką informację, ponieważ jest to informacja błędna ${ }^{44}$. Gramatyka języka hebrajskiego biblijnego nie pozwala nam na odczytanie קָּרָאת jako formy dla trzeciej osoby, ani męskiego, ani żeńskiego rodzaju:

41 Oczywiście autor Wulgaty nawiązuje w tym miejscu do królów Resina i Pekacha, którzy zawiązali koalicję syro-efraimską przeciw Achazowi, o czym wspominamy w podpunkcie 2 .

${ }_{42}$ Hieronymus, Commentaria in Isaiam 7, 14: ,Quodque sequitur: «Et vocabis nomen ejus Emmanuel», et LXX et tres reliqui similiter transtulerunt, pro quo in Matthaeo scriptum est, «vocabunt»: quod in Hebraeo non habetur. Ergo iste puer qui nascetur ex Virgine, o domus David, nunc a te appelletur «Emmanuel», id est, «nobiscum Deus», quia rebus ipsis probabis a duobus inimicis regibus liberata, Deum te habere praesentem" (tł. własne).

43 Por. Koehler - Baumgartner - Stamm, Wielki stownik hebrajsko-polski, t. 2, s. 189-192, nr 8287.

44 Jedynym logicznym argumentem, który pozwala nam przypuszczać, dlaczego komentator formę קִּרָ (2 sg. fem.) interpretuje jako trzecią osobę liczby pojedynczej, jest wyjaśnienie, iż Hieronim nie odczytuje w tym miejscu hebraica veritas zgodnie z literą gramatyki, lecz interpretuje cały werset w sensie profetycznym, ponieważ w Iz 7,14a jest mowa o ,pannie”, która porodzi dziecko, zatem ona nada mu imię. 
Czasownik CARATHI ${ }^{45}$, który wszyscy zinterpretowali [jako] „vocabis”46, można też odczytać [jako] „vocabit”47, ponieważ oczywiście owa Dziewica, która pocznie i porodzi, nazwie tym imieniem Chrystusa $^{48}$.

Teraz spróbujemy poszukać odpowiedzi na pytanie, kim w opinii Strydończyka jest tajemniczy Emmanuel? Otóż w sensie dosłownym chłopiec o imieniu Emmanuel, jak i jego matka powinni być osobami współczesnymi Achazowi (por. Iz 7,15-16; 8,8.10), gdyż ów znak, dany królowi przez Boga, ma być dla niego czytelny. Potwierdza to determinant

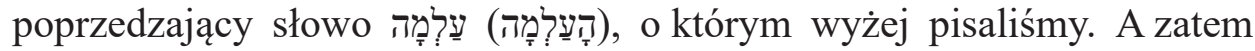
wszystko wskazuje na fakt, iż według interpretacji literalnej w tym wersecie jest mowa o żonie Achaza - Abijji i jej synu Ezechiaszu (por. 2Krl 18,2; 2Krn 29,1).

Hieronim, objaśniając poszczególne księgi biblijne, pragnie dotrzeć do sensu, który kryje się pod postacią słowa. W tym względzie kieruje się kilkoma zasadami hermeneutyki, spośród których warto wyliczyć następujące: wielość sensów Pisma Świętego, jego charakter wspólnotowy oraz chrystologiczny. Autor Wulgaty zakłada, że Biblia nie jest księga jednoznaczną, lecz zawiera w sobie niezmierne bogactwo treści, o czym pisze między innymi w Komentarzu do Koheleta 1, 8: „Należy podkreślić, że wszystkie słowa są brzemienne w treść i wymagają wielkiego wysiłku dla jej zgłębienia i nie jest tak - jak sądzą niektórzy, iż jakoby próżnując i czyniąc postanowienia, zdołali posiąść znajomość Pisma Świętego"49. Sens ten opiera się zasadniczo na dwóch przesłankach: po pierwsze całe Pismo Święte mówi o Chrystusie, po drugie całe Pismo Święte jest jedną całością. I w tym kluczu autor Wulgaty interpretuje ,proroctwo o Emmanuelu”, ponieważ dopatruje się u Iz 7,14b sensu typicznego i odnosi ów werset do Chrystusa: „I ten, który później będzie nazwany Jezusem, to znaczy,

45 Wydaje się, że Hieronimowa interpretacja tej formy czasownikowej jest błędna, a co najmniej kuriozalna. Najprawdopodobniej Strydończyk interpretuje to słowo wedle zasad języka syryjskiego, w którym w koniugacji p'al w perfectum dla drugiej osoby liczby pojedynczej rodzaju żeńskiego występuje sufiks - $t i$, a litera „i” jest niema, nawet jeśli jest zapisywana.

46 To znaczy 'nazwiesz'.

47 To znaczy 'nazwie'.

48 Hieronymus, Commentaria in Isaiam 7, 14: „Verbum CARATHI, quod omnes interpretati sunt «vocabis», potest intelligi et «vocabit»: quod ipsa scilicet Virgo quae concipiet et pariet, hoc Christum appellatura sit nomine" (tł. własne).

49 Zob. Św. Hieronim, Komentarz do Księgi Eklezjastesa, tł. K. Bardski, Kraków 1995 , s. 31. 
«Zbawicielem», przez to, że odkupi cały rodzaj ludzki, teraz przez ciebie, [o domu Dawida], został nazwany przy pomocy słowa Emmanuel"

Dalej autor Wulgaty, udowadniając swój chrystologiczny model interpretacji Iz 7,14b, powołuje się na symboliczne imię drugiego syna Izajasza, które podaje za przekazem wcześniejszych komentatorów, a których nie wylicza w tym miejscu imiennie (Quidam de nostris Isaiam prophetam duos filios habuisse contendit, Jasub ${ }^{51}$ et Emmanuel ${ }^{52}$ ). Nadanie symbolicznego imienia synowi Izajasza miałoby być zapowiedzią rychłego upadku koalicji syro-efraimskiej:

Niektórzy z naszych stanowczo twierdzą, że prorok Izajasz miał dwóch synów, Jaszuba i Emmanuela, i Emmanuel zrodzony z prorokini, żony Izajasza, jest prefigurą Pana Zbawiciela; jako że pierwszy syn - Jaszub, który znaczy „opuszczony” albo „powracający”, jest symbolem narodu żydowskiego, który został opuszczony [przez YHWH], a następnie powrócił [do Boga]. Drugi [syn] zaś - Emmanuel, [czyli] „z nami Bóg”, [symbolizuje] powołanie pogan, po tym jak „Słowo stało się ciałem i zamieszkało pośród nas” $(\mathrm{J} 1,14)^{53}$.

Św. Hieronim, trzymając się konsekwentnie swej interpretacji, iż Emmanuel z Izajaszowego proroctwa jest prefigurą Chrystusa, dokonuje relektury owego proroctwa, przywołując świadectwa z Ewangelii, które

50 Hieronymus, Commentaria in Isaiam 7, 14 (tł. własne).

51 Wedle przekazu Biblii hebrajskiej (por. Iz 7,3) pierwszy syn proroka nazywał się Szear-Jaszub (hebr. שִשָאר יָשוּב ralnie interpretować jako „reszta powróci” lub „reszta stanie się zmieniona”. Por. Koehler - Baumgartner - Stamm, Wielki stownik hebrajsko-polski, t. 2, s. 393, nr 9076.

52 W przypadku drugiego syna Izajasza Biblia hebrajska (por. Iz 8,3) podaje, iż miał

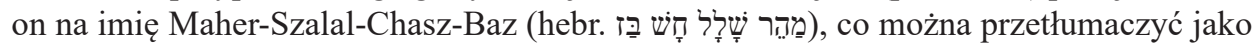
'rychły łup, szybka zdobycz'. Por. Koehler -Baumgartner - Stamm, Wielki słownik hebrajsko-polski, t. 1, s. 520-521, nr 4768. W interpretacji symbolicznej imię to zapowiada upadek koalicji królów Resina i Pekacha, którzy najechali na królestwo Achaza. Kwestią, która może budzić zdziwienie czytelnika, jest fakt, dlaczego Hieronim w komentarzu do Iz 7,14 nie koryguje informacji na temat imienia drugiego syna Izajasza, kiedy w swoim tłumaczeniu omawianego wersetu na język łaciński podąża za przekazem tekstu hebrajskiego, gdyż u Iz 7,14b w wersji Wulgaty czytamy „Accelera spolia detrahere; Festina prædari”. Wyjaśnienia nasuwają się co najmniej dwa. Po pierwsze, autor Wulgaty bardzo często w swoich komentarzach biblijnych podaje rozmaite przekazy (niekiedy sprzeczne ze sobą) na temat danej kwestii, nie zawsze je klasyfikuje, zestawia i wyciąga własne wnioski. Po drugie, w omawianym fragmencie powołuje się na stanowisko tzw. „niektórych z naszych" (łac. quidam de nostris), co może sugerować powątpiewanie w tę opinię.

53 Hieronymus, Commentaria in Isaiam 7, 14 (tł. własne). 
dotyczą Emmanuela, tj. Jezusa Chrystusa. Zasadnicza relektura rzeczonej mowy prorockiej znajduje się u Mt 1,23. Wydaje się, iż Ewangelista cytuje Iz 7,14 nie w celu wykazania dziewictwa matki Chrystusa, lecz koncentruje się na imieniu Mesjasza (por. 1,21-23), o czym już wyżej wspominaliśmy. Z kolei autor Wulgaty, poddając swej analizie Iz 7,15 (,Śmietanę i miód spożywać będzie, aby umiał odrzucać zło, a wybierać dobro”), powołuje się na werset z Łk 2,52, który w opinii Strydończyka należy odnieść do Emmanuela - Chrystusa:

I choć po wielu wiekach ewangelista o nim zaświadcza: „Chłopiec zaś wzrastał w mądrości, w latach i w łasce u Boga i ludzi” (Łk 2,52), a to zostało powiedziane, aby natura rodzaju ludzkiego została dowartościowana, jednak teraz jeszcze odziany w pieluszki i karmiony śmietaną i miodem otrzyma zdolność osądu zła i dobra, aby odrzucając zło, wybierał dobro ${ }^{54}$.

Następnie komentator według wykładni per figuram dopatruje się owego chłopca z Iz 7,14 w wybranych wydarzeniach z życia syna Maryi. Tym samym kolejny raz potwierdza, że Emmanuel jest prototypem Jezusa Chrystusa:

Wreszcie aniołowie oznajmiają pasterzom, że [on] leży w żłobie; magowie przychodzący ze Wschodu, o których mianowicie trzeba nam sądzić, że zostali wybrani, adorują [go]. Przeciwnie Herod, skrybowie i Faryzeusze byli ganieni (Mt 2), ponieważ za jednego chłopca zamordowali wiele tysięcy chłopców ${ }^{55}$.

\section{Konkluzja}

Po przeanalizowaniu wybranych passusów z Hieronimowego komentarza do Iz 7,10-16, które biblistyka klasyfikuje jako tzw. ,proroctwo o Emmanuelu", nasuwają się następujące wnioski. Po pierwsze, Hieronim, jak mówi o sobie samym w Apologii przeciw Rufinowi 3, 6 „Ego [...] Hebraeus, Graecus, Latinus, trilinguis", słusznie - w naszym przekonaniu zasługuje na miano vir trilinguis, ponieważ biegle i w dużej mierze trafnie,

54 Hieronymus, Commentaria in Isaiam 7, 15 (tł. własne).

55 Hieronymus, Commentaria in Isaiam 7, 15 (tł. własne). 
co próbowaliśmy wykazać, analizując Iz 7,10-16, posługuje się hebrajskim, greką i łaciną, zestawiając tekst oryginalny z greckimi tłumaczeniami: LXX, Akwilą, Symmachem i Teodocjonem. Hieronimowe uwagi filologiczne są w dużej mierze poprawne, co nie oznacza, że komentator nigdy się nie myli.

Po drugie, poszukując odpowiedzi na pytanie, w jaki sposób Strydończyk interpretuje ,proroctwo o Emmanuelu”, należy podkreślić, iż konsekwentnie przeprowadza wywód po linii egzegezy ponaddosłownej. Według tej interpretacji Izajaszowy Emmanuel jest typem Jezusa Chrystusa. Zatem autor Wulgaty odrzuca sens dosłowny omawianego fragmentu, który mówiłby o Ezechiaszu, którego miała porodzić żona króla Achaza, co byłoby znakiem trwałości dynastii Dawidowej według obietnicy Boga (por. $2 \mathrm{Sm} 7,16$ ).

\section{Jerome of Stridon as vir trilinguis on the Example of a Commentary to the Book of Isaiah 7:10-16}

(summary)

The article concerns Commentaria in Isaiam 7:10-16 (cf. PL 24, 107 A-113 B), which was written by St. Jerome of Stridon. In this article, I was looking for an answer to the question of how St. Jerome interprets „,The Emmanuel Prophecy": whether in the literal or allegorical sense? The literal interpretation of Isa 7:10-16 refers to the prophecy of Hezekiah, who was to give birth to the wife of King Ahaz (cf. 2Sam 7:1), the author of Vulgate sees a typical sense in this passage. So Emmanuel is a prefiguration of Jesus Christ („Qui postea vocabitur Jesus, id est, «Salvator», eo quod universum hominum genus salvaturus sit, nunc a te Emmanuelis appelletur vocabulo"; PL 24, 111 C). In my opinion, Commentaria in Isaiam 7:10-16 undoubtedly its value is interesting for researchers dealing with Ancient translations of the Bible, because St. Jerome - vir trilinguis (cf. Apologia adversus libros Rufini 3, 6, PL 23, 462A) who writes in Latin and uses Greek and Hebrew quite well, he copes with the criticism of the text by juxtaposing with the original Bible text the ancient translations available to him (LXX, Aquila, Symmachus and Theodotion).

Keywords: The Book of Isaiah; The Fathers of the Church; St. Jerome; A Commentary on the Book of Isaiah; Isa 7:10-16; The Emmanuel Prophecy; typology

\section{Hieronim ze Strydonu jako vir trilinguis na przykładzie komentarza do Iz 7,10-16 \\ (streszczenie)}

Św. Hieronim ze Strydonu, nazywany princeps exegetarum, utrwalił się w pamięci potomnych ogromną ilością dzieł. Najważniejszym dziełem i celem życia Hieronima była 
praca nad Pismem Świętym. Zabłysnął on również, objaśniając Pismo Święte. Stworzył wiele komentarzy biblijnych, zarówno dla ksiąg Starego, jak i Nowego Testamentu. W niniejszym artykule pochyliliśmy się nad Hieronimowym komentarzem do Iz 7,10-16 (Commentaria in Isaiam, PL 24, 107 A-113 B), poszukując odpowiedzi na pytanie, w jaki sposób Strydończyk interpretuje ,proroctwo o Emmanuelu”. Czy ów starożytny biblista interpretację mesjańską tego proroctwa wyjaśnia w sensie dosłownym i odnosi ją do Ezechiasza, którego miała porodzić żona króla Achaza, co miałoby być znakiem trwałości dynastii Dawidowej (por. 2Sm 7,16.25-26), czy może Hieronim dopatruje się tutaj sensu typicznego i odnosi ów passus do Chrystusa? Podjęliśmy także próbę ukazania na wybranych fragmentach, w jaki sposób Hieronim - vir trilinguis, piszący po łacinie, a posługujący się dość dobrze greką i hebrajskim, radzi sobie z krytyką tekstu, zestawiając $\mathrm{z}$ oryginalnym tekstem Biblii dostępne mu starożytne przekłady Iz 7,10-16. Fragmenty z Hieronimowego dzieła podaliśmy w tłumaczeniu własnym.

Słowa kluczowe: Księga Izajasza; Ojcowie Kościoła; Św. Hieronim; Komentarz do Księgi Izajasza; Iz 7,10-16; proroctwo o Emmanuelu; typologia

\section{Bibliografia}

\section{Źródła}

Augustinus, De civitate Dei, PL 41, 13-804.

Hieronymus, Apologia adversus libros Rufini, PL 23, 397-492.

Hieronymus, Commentarius in Ecclesiasten, ed. M. Adrien, Turnhout 1959, CCL 72,

247-361, tł. K. Bardski, Hieronim, Komentarz do Księgi Eklezjastesa, BOK 5, Kraków 1995, 24-152.

Hieronymus, Commentaria in Isaiam, PL 24, 17 A-704 B.

Hieronymus, Epistulae, PL 22, 325-1224, ŹMT 54; 55; 61; 63; 68, oprac. H. Pietras -

M. Ożóg, tł. J. Czuj, Kraków 2010-2013.

Hieronymus, Liber hebraicarum quaestionum in Genesim, PL 23, 935A-1010A,

tł. M. Jóźwiak, Kwestie hebrajskie w Księdze Rodzaju św. Hieronima. Przekład i komentarz, Wrocław 2010, s. 34-131.

Origenes, In Isaiam hom., ed. W.A. Baehrens, GCS 33, Berlin 1925, s. 242-289,

tł. S. Kalinkowski, Orygenes, Homilie o Księdze Izajasza, w: Orygenes, Homilie o Księgach Izajasza i Ezechiela, ŹMT 16, Kraków 2000.

\section{Opracowania}

Dulaey M., Victorin de Poetovio, premier exégète latin, Paris 1993.

Field F., Origenis Hexaplorum quae supersunt; sive Veterum Interpretum Graecorum in totum Vetus Testamentum fragmenta, t. 1-2, Oxford 1875. 
Gozzo S., De sancti Hieronymi commentario in Isaiae librum, „Antonianum” 35 (1960) s. $49-80$ i $169-214$.

Jay J., L'exégèse de Saint Jérôme d'après son „, Commentaire sur Isaïe”, Paris 1985.

Jóźwiak M., ,Princeps exegetarum” a język hebrajski na podstawie „, Quaestiones Hebraicae in Genesim”, „Vox Patrum” 65 (2016) s. 185-199.

Kelly J.-N.-D., Hieronim. Życie, Pisma, Spory, tł. R. Wiśniewski, Warszawa 2003.

Koehler L. - Baumgartner W. - Stamm J.J., Wielki słownik hebrajsko-polski i aramejsko-polski Starego Testamentu, t. 1-2, red. P. Dec, Warszawa 2008.

Królikowski J., Jak powstała Wulgata i któremu tekstowi Pisma Świętego przystuguje to miano?, „Tarnowskie Studia Teologiczne” 36 (2017) s. 5-20.

Manzanares C.-V., Pisarze wczesnochrześcijańscy I-VIII w. Mały słownik, tł. E. Burska, Warszawa 2001.

Simonetti M., Sulle fonti del Commento a Isaia di Girolamo, „Augustinianum” 24 (1984) s. 451-469.

Simonetti M., Między dostownościa a alegoria, tł. T. Skibiński, Kraków 2000. 